\title{
"SipTENAN" As an Innovative Relative Advantage in Building Permits Management in Pekalongan District
}

\author{
Herbasuki Nurcahyanto \\ \{herbasukinurcahyanto@lecturer.undip.ac.id\} \\ Universitas Diponegoro, Indonesia
}

\begin{abstract}
In order to facilitate the process of licensing Pekalongan District launched the innovation of The Integrated Licensing System of Pekalongan District known as "SipTENAN". This research aims to analyze the relative advantage of innovation "SipTENAN" program by using qualitative methods. The results show that "SipTENAN" innovation can make it easier for people to take care of Building Permit Management; this process becomes faster and more effective. This is indicated by an increase in the number of Building Permit Management applicants from 487 in 2017 to 2,303 in 2019. The mindset of people who are not familiar with the internet is an obstacle, so it is necessary to have a special desk for service and mentoring for users. The recommendations that can be delivered are the improvement of sustainable and community-oriented public services. Society needs to be given an understanding of innovations through socialization by engaging various parties such as: Non-Governmental Organizations, community organizations, high society and media.
\end{abstract}

Keywords: Relative Advantaging, Service Innovation, Pekalongan District

\section{Introduction}

Indonesia's Ease of Doing Business (EoDB) rating is currently ranked 73rd out of 190 countries in the world [1]. The rating is still far from the target set by President Mr. Joko Widodo, which is in 40th. Indonesia also recorded the lowest five in ASEAN in the Ease of Doing Business (EoDB) index with a score of 69.6. This figure is far from the score obtained by neighboring countries, namely Singapore that is ranked in second out of 190 countries and has a score of 86.2. Malaysia has a score of 81.5 and is ranked 12th in the world.

The government's efforts to improve public services by slashing the bureaucracy of licensing and non-licensing services, it is through One Door Integrated Service known as (PTSP). The regulation of [2] mandates that in order to provide regional licensing services form a one-door integrated service unit [3]. It is also to realize public services that are fast, easy, transparent, definitive, and affordable, and in order to provide wider access to the community to obtain good public services.

The next effort that has been made by the government by issuing The Government Regulation [4] on licensing services seeks to be integrated electronically through the Online Single Submission (OSS) system. Pekalongan District government has created "SipTENAN" online licensing application as a form of commitment to OSS. Applicants no longer need to travel a long distance and spend a long time to manage the creation of business licenses as well as non-striving licensing because the process of making licensing and non-attempting 
licensing in Pekalongan District can be implemented online through the application namely "SipTENAN".

Pekalongan District Government through the One Door Integrated Investment and Service Office launched a new breakthrough, namely the Integrated Licensing Service Information System of Pekalongan District that is known as ("SipTENAN"). To speed up and facilitate the licensing service process, the licensing process is done online on the website accessed on SipTENAN.pekalongankab.go.id. The online licensing service system started operating on May 1, 2018. One of the most widely managed types of licensing by the community is building permits known as (IMB). After the innovation of "SipTENAN" program there was a significant change in the number of permits issued by Investment Service (DPM), One Door Integrated Service (PTSP); Employment Agencies (NAKER) of Pekalongan District in recent years.

Table 1. Recapitulation of building permits of DPM PTSP and NAKER of Pekalongan District

\begin{tabular}{|l|c|c|c|c|}
\hline \multicolumn{1}{|c|}{ Month } & $\mathbf{2 0 1 7}$ & $\mathbf{2 0 1 8}$ & $\mathbf{2 0 1 9}$ & $\mathbf{2 0 2 0}$ \\
\hline January & 108 & 176 & 101 & 357 \\
\hline February & 2 & 112 & 20 & 249 \\
\hline March & 22 & 229 & 13 & 164 \\
\hline April & 14 & 155 & 168 & 405 \\
\hline Mei & 5 & 44 & 197 & 96 \\
\hline June & - & 51 & 25 & - \\
\hline July & - & 10 & 212 & - \\
\hline August & 6 & 120 & 598 & - \\
\hline September & 30 & 15 & 542 & - \\
\hline October & 30 & 144 & 103 & - \\
\hline November & 95 & 176 & 264 & - \\
\hline December & 175 & 287 & 60 & - \\
\hline Total & $\mathbf{4 8 7}$ & $\mathbf{1 . 5 1 9}$ & $\mathbf{2 . 3 0 3}$ & $\mathbf{1 . 2 1 7}$ \\
\hline
\end{tabular}

Source: DPM PTSP\& NAKER, June 2020.

Improving the service quality is in line with governance improvements made in unusual ways or in other words with public service innovation. Public service innovation is a breakthrough type of public service both original creative ideas as well as adaptations/modifications that benefit the community, both directly and indirectly [5]. This innovation does not only have to be a new invention, but also includes new approaches, expansion and quality improvement in existing public service innovations.

Zaltman et al. in Damanpour and Schneider [6] identified more than 21 attributes or characteristics of innovation. Rogers [7] mentioned five characteristics of innovation, namely relative advantage, compatibility, complexity, trainability, and observable [8]. Rogers explained that innovation [9] should have more advantages and value than previous innovations. There is always a value of novelty inherent in innovation that characterizes it from others.

Innovation was often defined in short and catchy phrases such as 'new ideas that work' [10] or 'new stuff that is made useful' [11]. Although such brief definitions might well capture the gist of the concept, we should here offer a more elaborate definition of innovation as an intended. Moreover inherently contingent, process that involves the development, adoption and spread of new and creative ideas that challenge conventional wisdom and bring about a qualitative change in the established practices within a specific context [12]. 
The level of profit or usefulness of an innovation can be measured based on its economic value, or from social status factors, pleasure, satisfaction, or having a very important component. The greater the relative advantage felt by adopters, the sooner the innovation is adopted. If the management of Building Permit requirements is complete then within 7 working days then it will be obtained. The acceleration of Building Permit management process time by using "SipTENAN" program application is much felt benefits for Building Permit applicants.

Researchers are interested in analyzing "SipTENAN's" innovations in the management of Building Permits (IMB) using relative advantage dimensions, because relative advantage is the best one dimension in the innovation process [13] Relative advantage has several sub dimensions that are directly related to perceptions of adopters about an innovation's contribution to potential organizational performance. Rogers in Tabak and Barr [8] identified the sub dimensions of "degree of economic profitability, low initial cost, a decrease in discomfort, a savings in time and effort, and the immediacy of the reward.

\section{Method}

This research site was conducted at Investment Service (DPM), One Door Integrated Service (PTSP); Employment Agencies (NAKER) of Pekalongan District by using qualitative research methods. The data collection techniques used by researchers are interviews, observations and documentation. The types of data used by researchers are primary and secondary data. The informant selection technique used by researchers in this study is to assign key informants. Data analysis used is an exploratory descriptive analysis technique [14].

\section{Result and Discussion}

The Integrated Licensing Service Information System of Pekalongan District namely "SipTENAN" is an innovation issued by Investment Service (DPM), One Door Integrated Service (PTSP); Employment Agencies (NAKER) of Pekalongan District. This innovation is in order to accelerate while simplifying the licensing service process conducted through online system. The implementation of public service innovation in the form of "SipTENAN" can be seen from several attributes of innovation. Researchers will only focus on researching the management of Building Permits known as (IMB) using relative advantage attributes.

Relative advantage is a level of innovation that has more advantages and value than the ideas they replace. New methods resulting from innovation aim to address problems that occurred before innovation and as an effort to improve public services. The relative advantages of an innovation can be measured from various ways such as economic value, comfort, prestige or social status benefits, ease of work, speed of work, and public enjoyment/satisfaction [15].

First, the economic value, the implementation of "SipTENAN" public service innovation is considered to provide economic benefits, both felt by Investment Service (DPM), One Door Integrated Service (PTSP); Employment Agencies (NAKER) of Pekalongan District as service providers and the community itself as the recipient of the service. The results shows that Investment Service (DPM), One Door Integrated Service (PTSP); Employment Agencies 
(NAKER) of Pekalongan District can make cost savings on Building Permit processes due to the online process and the increasing number of applicants.

Second, the convenience of utilizing, the results show that the presence of "SipTENAN" makes the licensing applicant feel comfortable because the licensing process can be done anywhere and anytime through online system, eliminating the practice of intermediaries or touts because the licensing procedure is clear and easy, and the licensing applicant can also track the application process through "SipTENAN" application program.

Third, the benefits on prestige or social status, the results show that the existence of "SipTENAN" has changed people's view of Investment Service (DPM), One Door Integrated Service (PTSP); Employment Agencies (NAKER) of Pekalongan District. Prior to "SipTENAN's" innovation, licensing was done manually by taking care in the office related to complicated procedures and took a considerable time. However, after the arrival of "SipTENAN" innovations program that can be done through online system, the licensing process becomes easier, cheaper, and faster. Investment Service (DPM), One Door Integrated Service (PTSP); Employment Agencies (NAKER) of Pekalongan District finally received appreciation from the community and received the award as the best One Gate Integrated System nominee from Ministry of Administrative and Bureaucratic Reform in 2019. "SipTENAN" innovation also makes Investment Service (DPM), One Door Integrated Service (PTSP); Employment Agencies (NAKER) of Pekalongan District several times gets work visits or comparative studies from other local governments, such as Regional Representative of Bandung District, Regional Representative of Kudus District, and Municipal Representative of the Manpower Ministry of Kulon Progo District. Indirectly the social status of Investment Service (DPM), One Door Integrated Service (PTSP); Employment Agencies (NAKER) of Pekalongan District through "SipTENAN" is raised.

Fourth, ease of work, the presence of "SipTENAN" innovation makes Investment Service (DPM), One Door Integrated Service (PTSP); Employment Agencies (NAKER) of Pekalongan District considered providing services faster and less convoluted, especially in licensing. The performance of Investment Service (DPM), One Door Integrated Service (PTSP); Employment Agencies (NAKER) of Pekalongan District became more organized, transparent, and accountable by using online systems.

Fifth, working speed, the result shows that with the presence of "SipTENAN" the licensing process time can be faster that is seven business days. Time efficiency also affects the number of applicants that can be served.

Sixth, the satisfaction of the community, excitement and satisfaction are conditions when someone gets something in line with their expectations. The implementation of public service innovation that goes well and provides benefits will provide a sense of pleasure and satisfaction for the community as the service beneficiary. The results show that the community as service beneficiary was satisfied with the existence of Investment Service (DPM), One Door Integrated Service (PTSP); Employment Agencies (NAKER) of Pekalongan District. This can be seen from the increasing value of public satisfaction surveys, namely in 2017 amount 71, 01 and in 2018 amount 76.62 and in 2019 amount 83.28.

Bases on the analysis results, "SipTENAN" that is issued by Investment Service (DPM), One Door Integrated Service (PTSP); Employment Agencies (NAKER) of Pekalongan District is one example in the implementation of agile government concept. Agile Government is the application of agile and responsive management systems (usually owned by private companies) into government management through the creation of adaptive organizational structures, utilization of information technology, and anticipatory to disruptive environments [16]. This aims to improve the organization's performance and productivity processes [17] 
The agile government concept expects public organizations to have a more efficient management system with broader and comprehensive utilization of information technologies such as big data analytics, artificial intelligence, and Internet of Things (IoT). Through the capabilities and capacity of organizations in running Communication Information Technology (ICT), organizations will be easier to be nimble and innovative especially facing the challenges of environmental change so as to achieve time efficiency and costs incurred. The service process also becomes fast, precise, productive, and efficient. On the other hand, the use of Communication Information Technology (ICT) in bureaucracy, especially in the implementation of "SipTENAN" has several obstacles. It is such as the condition or level of public mastery about the internet is still low so that the management of Building Permit remains served manually with the help of local officers and infrastructure that is not yet entirely ready with electricity and internet system.

\section{Conclusion}

The recommendations that can be delivered are the improvement of sustainable and community-oriented public services. Society needs to be given an understanding of innovations through socialization by engaging various parties such as: non-governmental organizations, community organizations, high society and media. Therefore, the public services that are provided can run efficiently and effectively.

\section{References}

[1] World Bank Group, "Doing business 2020 : comparing business regulation in 190 economies."

[2] Pemerintah Republik Indonesia, "Undang-Undang Republik Indonesia Nomor 23 tahun 2014 tentang Pemerintahan Daerah,” Kementeri. Sekr. Negara RI, 2014.

[3] "Undang-Undang Nomor 23 Tahun 2014."

[4] Pemerintah Republik Indonesia, "Peraturan Pemerintah Republik Indonesia No 24 Tahun 2018," p. 61, 2018.

[5] "Peraturan Menteri Pendayagunaan Aparatur Negara dan Reformasi Birokrasi Republik Indonesia Nomor 30 Tahun 2014."

[6] F. Damanpour and M. Schneider, "Characteristics of innovation and innovation adoption in public organizations: Assessing the role of managers," J. public Adm. Res. theory, vol. 19, no. 3, pp. 495-522, 2009.

[7] C. R. Rogers, "The interpersonal relationship," Harv. Educ. Rev., vol. 32, no. 4, pp. 416-429, 1962.

[8] F. Tabak and S. H. Barr, "Innovation attributes and category membership: Explaining intention to adopt technological innovations in strategic decision making contexts," J. High Technol. Manag. Res., vol. 9, no. 1, pp. 17-33, 1998.

[9] T. Yuniningsih, E. Larasati, N. Lutfiana, D. Hariani, and S. Sulandari, "Relative Advantage Dimensions In The Online Health Information System (SINAKES) In Semarang City of Central Java,” J. Appl. Sci. Eng. Technol. Educ., vol. 2, no. 1, pp. 58-68, 2020.

[10] C. Bloch, M. Bugge, and S. Slipersaeter, "Measuring Innovation in the Public Sector-Key Issues and Concepts," in Danish centre for studies in research and research policy (CFA), university of Aarhus, Denmark. Available: www. enid-europe. org/conf/abstracts/Bloch, 2010, vol. 20.

[11] M. T. Hansen and J. Birkinshaw, "The innovation value chain," Harv. Bus. Rev., vol. 85, no. 6, p. 121, 2007.

[12] E. Sørensen and J. Torfing, "Enhancing collaborative innovation in the public sector," Adm. 
Soc., vol. 43, no. 8, pp. 842-868, 2011.

[13] E. M. Rogers, A. Singhal, and M. M. Quinlan, "Diffusion of Innovations 1," in An Integrated Approach to Communication Theory and Research, Routledge, 2019, pp. 415-434.

[14] J. W. Creswell and C. N. Poth, Qualitative inquiry and research design: Choosing among five approaches. Sage publications, 2016.

[15] Y. Suwarno, "Inovasi Di Sektor Publik," J. Adm. Publik, vol. 5, no. 2, 2008.

[16] W. Kumorotomo, “Agile Government (Pemerintah Cergas)," 2019.

[17] A. J. H. de O. Luna, P. Kruchten, and H. P. de Moura, "Agile governance theory: conceptual development," arXiv Prepr. arXiv1505.06701, 2015. 